\title{
EFFECT OF SOCIO ECONOMIC STATUS ON JOB SATISFACTION LEVEL OF THE FEMALE WORKFORCE ENGAGED IN ELECTRONIC WATCH
} ASSEMBLY UNIT

\author{
BHUPENDER OULAKH \& DEEPA VINAY
}

Department of Family Resource Management, College of Home Science,

G.B. Pant university of Agriculture and Technology, Pantnagar, U.S. Nagar, Uttarakhand, India

\begin{abstract}
Job satisfaction can be defined as worker's positive or negative attitude toward their job. It is a worker's sense of achievement and success on the job. It is affected by various internal and external factors which may varies over a period of time. So, the employee's job satisfaction survey was conducted in electronic watch assembly unit to identifying the factors that affect the worker's job satisfaction in relation to socio-economic status. One hundred and twenty female employees were selected purposively from various assembly lines for conducting a survey. The study concluded that female employees had medium level of job satisfaction and found that socio-economic variables do influence the level of job satisfaction. The present study clearly stated that there is a significant relationship exists between job satisfaction and socio economic status of the employees.

KEYWORDS: Employees, Female Workforce, Job Satisfaction, Electronic Watch Assembly Unit \& Socio Economic Status
\end{abstract}

Received: Apr 17, 2017; Accepted: May 16, 2017; Published: Jun 06, 2017; Paper Id.: IJASRJUN201752

\section{INTRODUCTION}

An employee may be defined as a person, who works for an organization and move to various firms throughout their lives to earn livelihood. In the organization, workers are employed to use their skill, knowledge, experience and strength to increase the productivity of the organization. Job satisfaction can be defined as worker's positive or negative attitude toward their job. It is a worker's sense of achievement and success on the job. It is affected by various internal and external factors, which may vary over a period of time. For that, worker's job satisfaction is noted to be important for growth and success of the organization. In every organization, workers face too many barriers, which influenced the behavior and feeling of the workers. Positive and favorable feelings/attitudes of the employees towards the job indicate high job satisfaction, whereas negative and unfavorable feelings/attitudes towards the job indicate job dissatisfaction (Armstrong, 2006). Today every organization works for the employees comfort, safety and happiness to enhance the work productivity. It is because employees are among the most important key factors that determine the success of an organization in a competitive environment. Besides that, if managed properly employee commitment can lead to beneficial consequences such as increased effectiveness, performance, and productivity, and decreased turnover and absenteeism at both the individual and organizational level (Fiorita et al., 2007). An employee who is satisfied with his job would perform his duties well and be committed to his job, and subsequently to his organization. 
Thus, it is essential for employers to cognize the factors that can affect their workers' job satisfaction level since it would affect the performance of the organization as well (Awang et al., 2010).

On the other contrary, Judge et al. (2001) found that employee satisfaction is positively correlated with motivation, job involvement, organizational citizenship behavior, organizational commitment, life satisfaction, mental health, and job performance, and negatively related to absenteeism, turnover, and perceived stress. These factors identified as the degree to which a person feels satisfied by his/her job.

According to Freeman and Shelly (2005), the success of any organization directly depends on the employee's satisfaction who introduces that organization, that retaining talented people is critical to the success of any organization. Previous studies showed that businesses that excel in employee satisfaction issues reduce turnover by 50\% from the norms, increase customer satisfaction to an average of $95 \%$ \& lower labor cost by $12 \%$ (Carpitella, 2003). Hence, there is a strong link between employee satisfaction and customer satisfaction and between customer satisfaction and future revenue.

\section{Socio Economic Status and Female Workers}

Socioeconomic status is a measure of class standing, typically indicated by income, occupational prestige, educational attainment and wealth. But, in the present study, the term "Socio-Economic Status"e has considered in the sense of level of income, level of personal education, family occupation and social position in the society. Job satisfaction is not independent in all job facets and that satisfaction with one facet might lead to satisfaction with another (Crossman and Zaki, 2003). Mohammad et al. (2008) concluded in their study that variables such as employees' age, gender, work experience years, organizational position, type of employment and salaries received, and benefits were seen as having significant effects on their job satisfaction.

Therefore, the present study was planned with the objective to assess the satisfaction level of employees in relation to their socio economic status and identify the factors which influence and improve the job satisfaction of employees.

\section{MATERIALS AND METHODS}

A descriptive research design with survey method was applied in the study and questionnaire was used to collect data. The questionnaire consisted of three sections: 1) Personal Details, 2) Job satisfaction scale and 3) Socio economic status scale.

Job satisfaction was measured by using the job satisfaction scale developed by Sharma (2001). In case of Job satisfaction, scoring has been obtained on a five-point scale, (1= Highly Dissatisfied, 2= Dissatisfied, 3=Neutral, 4= Satisfied, and 5= Highly Satisfied) the range of score was 41 to 100. Higher score indicates greater job satisfaction. For better precision of the collected data and convenience in understanding the job satisfaction level of the respondents, the score was categorized on the basis of metric approach. The job satisfaction scores of the respondents were categorized as follows.

$\begin{array}{ll}\text { Category } & \text { Score } \\ \text { Low } & 41 \text { to } 60 \\ \text { Moderate } & 61 \text { to } 80\end{array}$


High $\quad 81$ to 100

SES was measured by using Socio economic status scale developed by Aggarwal et al. (2005). As a first step, total score has been computed and then it was divided into five groups namely: Upper High SES, High SES, Middle SES, Low Middle SES and Low SES.

After collecting the data, the data were edited and coded. The data were then analyzed using various statistical tools like mean, standard deviation, t-test, chi-square, coefficient of correlation and ANOVA.

\section{RESULTS AND DISCUSSIONS}

The survey was conducted in watch assembly unit and the participants' attributes are shown in Table 1.

Table 1: Demographic Characteristics of the Female Workforce $(n=120)$

\begin{tabular}{|c|c|c|}
\hline Demographic Characteristics & Number $(\%) *$ & Mean \pm SD \\
\hline $\begin{aligned} \text { Age } & \\
- & 20-22 \\
- & 23-25 \\
\bullet & 26-28\end{aligned}$ & $\begin{array}{c}51(42.50 \%) \\
65(54.17 \%) \\
4(3.33 \%)\end{array}$ & $22.64 \pm 1.53$ \\
\hline $\begin{array}{cl}\text { Marital } & \text { Status } \\
\bullet & \text { Married } \\
\bullet & \text { Unmarried }\end{array}$ & $\begin{array}{c}20(16.66 \%) \\
100(83.33 \%)\end{array}$ & \\
\hline 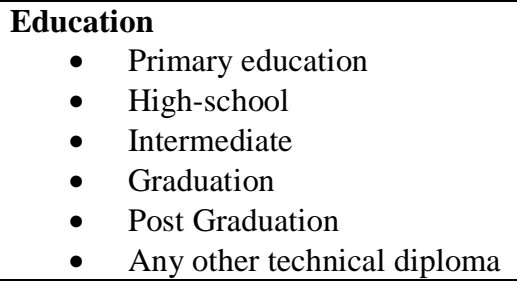 & $\begin{array}{c}1(0.83 \%) \\
8(6.67 \%) \\
71(59.16 \%) \\
26(21.67 \%) \\
14(11.67 \%)\end{array}$ & $4.36 \pm 0.80$ \\
\hline $\begin{array}{cl}\text { Assembly Line } \\
\bullet \quad \text { Manual } \\
\bullet \quad \text { Automatic }\end{array}$ & $\begin{array}{l}80(66.67 \%) \\
40(33.33 \%)\end{array}$ & \\
\hline $\begin{array}{cl}\text { Job Experience } \\
\text { - } & 1-2 \mathrm{yr} . \\
\bullet & 2-3 y r \\
\bullet & 3-4 y r \\
\bullet & 4-5 y r \\
\bullet & >5 y r \\
\end{array}$ & $\begin{array}{l}12(10.00 \%) \\
34(28.33 \%) \\
40(33.33 \%) \\
31(25.83 \%) \\
3(2.5 \%)\end{array}$ & $3.6 \pm 1.0$ \\
\hline $\begin{aligned} & \text { Caste } \\
&- \text { General } \\
&- \mathrm{OBC} \\
&- \mathrm{SC} \\
&\end{aligned}$ & $\begin{array}{c}102(85.00 \%) \\
13(10.83 \%) \\
5(4.16 \%)\end{array}$ & \\
\hline $\begin{array}{cl}\text { Family } & \text { Type } \\
\bullet & \text { Single } \\
\bullet & \text { Joint }\end{array}$ & $\begin{array}{l}78(65.00 \%) \\
42(35.00 \%)\end{array}$ & \\
\hline $\begin{array}{ll}\text { Source of Family Income } \\
\text { - } \\
\text { - } \\
\text { - } & \text { Agriculary } \\
\text { - } & \text { Agriculture related any other } \\
\end{array}$ & $\begin{array}{c}70(58.33 \%) \\
19(15.83 \%) \\
3(2.5 \%) \\
28(23.33 \%)\end{array}$ & \\
\hline $\begin{array}{c}\text { Repetitive Task Daily } \\
\text { - Yes } \\
\text { - No }\end{array}$ & $\begin{array}{l}98(81.67 \%) \\
22(18.33 \%)\end{array}$ & \\
\hline
\end{tabular}

*Percentage is given in parenthesis. 
All the selected employees participated in job satisfaction survey. More than half of the employees (54.17 percent) belonged to the age group of 23-25 years, and most of the employees were unmarried (83.33 percent). For educational background, maximum employees (59.16 percent) were graduates. More than half of the employees (66.67 percent) worked in the manual assembly line, whereas 33.33 percent worked in automatic assembly line. Maximum employees (33.3 percent) have 3-4years job experience in assembly work, and the same percentage belonged to general category. In total, 65 percent employees having single family type and 58.33 percent employees said that salary was the only source of their family income. Most of the employees ( 81.67 percent) were performed same task daily in the assembly shop.

\section{Level of Job Satisfaction}

The present study explored key areas of job satisfaction using the Sharma (2001) Satisfaction Scale. It is a 5-point Likert scale (5=Highly satisfied to 1=Highly dissatisfied) comprising 20 items on eight dimensions: standard of living, pay and promotion, balance of family and work, co-workers, interaction opportunities, professional opportunities, praise and recognition, control and responsibility. The satisfaction scale's correlation coefficient was reported as 0.95 . Responses were scored on all twenty statements and later on the total score was obtained (Table 2).

Table 2: Level of Job Satisfaction

\begin{tabular}{|c|l|c|c|c|}
\hline S. No & Level of Job Satisfaction & Frequency & Percent & \multirow{2}{*}{ Mean \pm SD } \\
\hline 1 & Low level (41-60) & 19 & 15.83 & \\
\cline { 1 - 3 } 2 & Medium level (61-80) & 61 & 50.83 & \multirow{3}{*}{$33.33 \pm 17.5$} \\
\hline 3 & High level (81-100) & 40 & 33.33 & \\
\cline { 1 - 3 } & Total & $\mathbf{1 2 0}$ & $\mathbf{1 0 0 . 0 0}$ & \\
\hline
\end{tabular}

The results demonstrated that half of the employees (50.83 percent) had medium level of job satisfaction, more than two-fifth of them (33.33 percent) had high level of job satisfaction and around one-fifth of them (15.83 percent) had a low level of job satisfaction. The mean job satisfaction score of the employees was 33.33 and standard deviation was 17.5 . From this it is clear that majority of the employees had medium level of job satisfaction. Similar study has done by Jain et al. (2007) reveal that individuals show pleasurable positive attitudes when they are satisfied with their job.

\section{H01: There is No Significant Relationship Between}

- Monthly Income and Job Satisfaction

- Education and Job satisfaction

- Family possession and job satisfaction

- $\quad$ Caste and job satisfaction

- Occupation and Job Satisfaction

The Chi-square $\left(\chi^{2}=468.69\right)$ shown that there is a significant relationship between the employee's monthly income and level of job satisfaction at $\mathrm{p}<0.01$ level of significance. From this it can be interpreted that monthly income was not only the single factor which was responsible for the job satisfaction of the employees. An employee who was satisfied with his monthly income may not have job satisfaction even if other factors influence him. This is the reason job satisfaction level of the employees is dependent upon the various factors other than monthly income. This finding was similar to the finding of earlier study which revealed that there is significant relationship between monthly income and level of satisfaction (Sukumar, 
2009). Fiorita et al., (2007) found that

Table 3: Chi-Square Values $\left(\chi^{2}\right)$ for Socio-Economic Factors and Level of Job Satisfaction

\begin{tabular}{|c|l|c|c|}
\hline S. No & \multicolumn{1}{|c|}{ Variables } & Statistical Tool & Result \\
\hline $\mathbf{1}$ & Monthly Income and Job Satisfaction & $\chi^{2}=468.69,(\mathrm{p}<0.01)$ & Significant \\
\hline $\mathbf{2}$ & Education and Job satisfaction & $\chi^{2}=950.24,(\mathrm{p}<0.01)$ & Significant \\
\hline $\mathbf{3}$ & Family possession and job satisfaction & $\chi^{2}=1094.65,(\mathrm{p}<0.01)$ & Significant \\
\hline $\mathbf{4}$ & Caste and job satisfaction & $\chi^{2}=1056.06,(\mathrm{p}<0.01)$ & Significant \\
\hline $\mathbf{5}$ & Occupation and Job Satisfaction & $\chi^{2}=938.57,(\mathrm{p}<0.01)$ & Significant \\
\hline
\end{tabular}

Job satisfaction is not independent in all job facets and that satisfaction with one facet might lead to satisfaction with another. Employees were found to be less satisfied with all facets except pay.

The value of Chi-square $\left(\chi^{2}=950.24\right)$ shown that there is a significant difference in the level of job satisfaction of the employees in relations to their education qualification at $\mathrm{p}<0.01$ level. It can be concluded that educational qualification influences the level of job satisfaction of the employees. The above finding is supported by previous study which clearly stated that there is significant relationship between educational qualification and level of satisfaction (Sukumar, 2009). Employees with lower educational qualifications were least satisfied (Fiorita et al., 2007).

The Chi-square value $\left(\chi^{2}=1094.65\right)$ shown that there is significant difference in the level of job satisfaction of the employees with respect to their family possession at $\mathrm{p}<0.01$ level of significance. It shows that family possessions help to reduce the work stress which leads to job satisfaction of the employees.

The value of chi-square $\left(\chi^{2}=1056.06\right)$ shown that there is significant difference in the level of job satisfaction of the employees with respect to their caste at $\mathrm{p}<0.01$ level of significance. It shows that caste helped to the employees to get job which leads to the high level of job satisfaction.

The chi-square value $\left(\chi^{2}=938.57\right)$ shown that there is a significant difference in the level of job satisfaction of the employees in relations to their occupation at $\mathrm{p}<0.01$ level. It can be concluded that type of job influences the level of job satisfaction of the respondents. The similar finding was found in the study conducted by the Sukumar (2009) that there is significant relationship between nature of job and level of satisfaction.

\section{$\mathrm{Ho}_{2}$ : There is No Significant Relationship between Socio Economic Status and Employee Job Satisfaction}

Table 4: Chi-Square Values $\left(\chi^{2}\right)$ for Relationship between
Job Satisfaction and Socio-Economic Status
\begin{tabular}{|c|c|c|}
\hline & $\chi^{2}$ Value & Result \\
\hline SES and Job Satisfaction & $235.28,(\mathrm{p}<0.01)$ & Significant \\
\hline
\end{tabular}

The value of chi-square $\left(\chi^{2}=235.28\right)$ was highly significant at $\mathrm{p}<0.01$ level of significance. It can be concluded that socio-economic status represents individual position in the society and leads to job satisfaction of the employees. The finding was similar to the study done by Barman and Bhattacharyya (2012) revealed that there exist significant relationship between Job Satisfaction and Socio-Economic Status of Para Teachers.

\section{CONCLUSIONS}

Job Satisfaction is one of the most important factors, which can motivate workers to perform better in the organization. They act as the wheel for organization and organization cannot move a little bit without them. If the workers are satisfied with their job, it becomes strength of the organization. Therefore, worker's job satisfaction survey should be 
conducted in the organization to identify the needs, wants and problems of the workers. The study concluded that female employees of watch assembly industry had medium level of job satisfaction and found that socio-economic variables do influences the level of job satisfaction. The present study clearly stated that there is a significant relationship exists between job satisfaction and socio economic status of the employees.

\section{ACKNOWLEDGEMENT S}

The researchers would like to acknowledge the financial contributions from Ministry of Science, Technology and Innovation (DST INSIPRE).

\section{REFERENCES}

1. Aggrawal, O.P.; Bhasin, S.K.; Sharma, A.K.; Chhabra, P.; Aggarwal, K. and Rajoura, O.P. (2005). New Instrument (scale) for Measuring the Socioeconomic Status of a Family: Preliminary Study. Indian Journal of Community Medicine, 30(4):111114.

2. Armstrong, M. (2006). A Handbook of Human resource Management Practice. Tenth Edition. Kogan Page Publishing, London. p. 264.

3. Awang, Z.; Ahmad, J. H. and Zin, N. M. (2010). Modelling Job Satisfaction And Work Commitment Among Lecturers: A Case of UiTM Kelantan. Journal of Statistical Modeling and Analytics, 1(2): 45-59.

4. Barman, P. \& Bhattacharyya, D. (2012). Job satisfaction of para teachers in relation to their socio-economic status in the district of Burdwan. International Journal of Research in Social Sciences and Humanities. 1(5)

5. Carpitella, B. (2003). Make residential construction the industry of choice [Electronic version]. Professional Builder, Oct 2003.

6. Crossman, A. \& Zaki, B. (2003). Job satisfaction and employee performance of Lebanese banking staff. Journal of Managerial Psychology, 18(4), $368-376$.

7. Fiorita, J. A.; Bozeman, D. P.; Young, A. \& Meurs, J. A. (2007). Organization Commitment, Human Resource Practices and Organization Characteristic. Journal of Managerial, 19(2), 186-207.

8. Freeman, S. (2005). Employee satisfaction: The key to a successful company. Retrieved on March15,2011.http://library.lp.findlaw.com/articles/file/00301/008927/title/Subject/topic/Employment.

9. Jain, K.K.; Jabeen, F.; Mishra, V. \& Gupta, N. (2007). Job Satisfaction as Related to Organizational Climate and Occupational Stress: A Case Study of Indian Oil. International Review of Business Research Papers 3(5), 193-208.

10. Judge, T.A.; Thoresen, C. J.; Bono, J. E. \& Patton, G. K. (2001). The Job Satisfaction-Job Performance Relationship: A Qualitative and Quantitative Review. Psychological Bulletin, 127(3), 376-407.

11. Mohammad, A.; Ferlie, E. \& Rosenberg, D. (2008). A study of the relationship between job satisfaction, organizational commitment and turnover intention among hospital employees. Health Services Management Research, 21(4), 211-227.

12. Sharma, D, (2001). Study and development of entrepreneurial characteristics among self employed rural women. Ph.D. Thesis. M.S. University of Baroda.

13. Sukumar, M. (2009). Study on job satisfaction among the employees of state bank of India in Coimbatore city. 